日植病報 $35: 160-167$ (1969)

Ann. Phytopath. Soc. Japan $35: 160-167$ (1969)

\title{
Formation of Lignin-like Substance in the Root Tissues of Japanese Raddish Plant Infected by Downy Mildew Fungus*
}

\author{
Yasuji Asada** and Isao Matsumoto** \\ 浅田泰次**・松本 勲**：ベと病菌に感染したダイコン根組織内に拈ける \\ リグニン様物質の生成
}

\begin{abstract}
A lignin-like substance (LS) has been found in roots of Japanese radish infected by Peronospora parasitica. From infrared and ultraviolet absorption spectra, methoxyl content, and paper chromatograms of the degradation products, it was confirmed that LS from infected roots is different from wood lignin. This substance was not found in healthy parenchyma. Living tissues alone were capable of forming this substance. Histochemical reactions by phloroglucinol-HCl and Loele's reagents revealed that high peroxidase activity was located around the lignified cell walls. All cells in the sections were alive judging from plasmolysis except those on the cut surface. However, we could not determine exactly whether the lignification of cell walls had taken place before or after the fungal attack. Lignification in cell walls of parenchyma was incomplete even when the cells were infected.

(Received March 19, 1968)
\end{abstract}

\section{Introduction}

Nutritional physiology of the obligate parasite and the defense reaction of a host to the parasite are interesting problems to both the plant pathologists and biochemists. In the previous paper ${ }^{1)}$, we reported the formation of lignin in the root tissues of Japanese radish affected by Alternaria japonica. In order to compare the reactions between facultative saprophyte and obligate parasite, we studied the lignin formation in the root infected by Peronospora parasitica.

\section{Material and methods}

Inoculation Well-developed roots of about 3-month-old Japanese radish (Raphanus sativus L. var. hortensis Backer) were obtained from the market. The roots (ca. $5 \mathrm{~cm}$ in diam.) were aseptically cut into slices about $1 \mathrm{~cm}$ thick. The slice were inoculated with conidia of Peronospora parasitica Pers. ex Fr. ( $P$. brassicae Gäum. $)^{11)}$. The conidia were collected from infected leaves by keeping them in moistened petri dishes for one night. Inoculated slices were incubated in moistened petri dishes at $20^{\circ} \mathrm{C}$ under 110 lux illumination from white fluorescent lamps.

Histochemical reagents and plasmolysis Slices of parenchyma, about $50 \mu$ thick were pre-

* This paper constitutes Part 2 of the Lignin Formation in Fungus Infected Plants. Part 1 is Formation of Lignin in the Root Tissues of Japanese Radish Affected by Alternaria japonica, Phytopathology $57: 1339,1967$.

** College of Agriculture, Ehime University, Matsuyama, Japan. Laboratory of Plant Pathology, Contribution (N.S.) No. 3. 愛媛大学農学部 
pared by a freezing microtome. Phloroglucinol-HCl reagent was added to slices to identify the presence of lignin. Peroxidase was identified by Loele's reagent ${ }^{5)}$. For observing plasmolysis, hand-sectioned slices were dipped into $0.4 \mathrm{M} \mathrm{KCl}$ for $30 \mathrm{~min}$.

Isolation and quantitative determination of lignin. Twenty $\mathrm{g}$ of powder (30-mesh) were prepared from dried slices. This powder was suspended in $1 l$ of hot water for $12 \mathrm{hr}$ and filtered twice. The residue was extracted with $2 l$ of $0.5 \%$ ammonium oxalate at $85^{\circ} \mathrm{C}$ for $30 \mathrm{hr}$ and filtered, followed by extration of the residue again with $1 l$ of $2 \% \mathrm{Na}_{2} \mathrm{CO}_{3}$ for $12 \mathrm{hr}$. After drying the residue at $40^{\circ} \mathrm{C}$, the powder obtained was extracted with $100 \mathrm{ml}$ of benzeneethanol $(1: 1)$ at about $80^{\circ} \mathrm{C}$ for $12 \mathrm{hr}$. Then the residue was extracted with $200 \mathrm{ml}$ of dioxane containing $3 \mathrm{ml}$ of $12 \mathrm{~N} \mathrm{HCl}$ at about $90^{\circ} \mathrm{C}$ for $12 \mathrm{hr}$. The filtered residue was washed with dioxane. The filtrate and dioxane washings were neutralized with solid $\mathrm{NaHCO}_{3}$. The filtrate was distilled under reduced pressure and about $50 \mathrm{ml}$ of concentrated solution were added to $400 \mathrm{ml}$ of $\mathrm{HCl}$ solution ( $\mathrm{pH} 2$ ), centrifuging at $1,600 \times \mathrm{g}$ for $20 \mathrm{~min}$. After washing the centrifuged material with $200 \mathrm{~m} l$ of water, the pellet was dissolved in $10 \mathrm{~m} l$ of dioxane, $400 \mathrm{~m} l$ of ether added and the suspension was centrifuged twice at $1,600 \times \mathrm{g}$ for $20 \mathrm{~min}$. The final precipitate is designated as "dioxane lignin-like substance" (DLS).

Quantitative determination of lignin content was made as follows: Five hundred mg of powder, extracted with benzene-ethanol mixture (mentioned above), were treated with $0.5 \mathrm{~g}$ thioglycolic acid in $5 \mathrm{ml}$ of $2 \mathrm{~N} \mathrm{HCl}$ at about $90^{\circ} \mathrm{C}$ for $5 \mathrm{hr}$, and filtered through a glass filter. The residue was extracted with $5 \mathrm{ml}$ of $2 \% \mathrm{NaOH}$ at room temperature for $24 \mathrm{hr}$. The filtered residue was suspended in $10 \mathrm{ml}$ of water for a few minutes. The filtrate and water washings were acidified to $\mathrm{pH} 1.5$ with $5 \mathrm{~N} \mathrm{HCl}$ and centrifuged at $1,600 \times \mathrm{g}$ for $20 \mathrm{~min}$. The precipitate was washed with $10 \mathrm{~m} l$ of water and centrifuged at $1,600 \times \mathrm{g}$ for $20 \mathrm{~min}$. The pellet was extracted with $10 \mathrm{~m} l$ of ether and centrifuged again. The final precipitate was dissolved in $5 \mathrm{ml}$ of $\mathrm{N}, \mathrm{N}$-dimethylformamide and the absorbance was determined at $278 \mathrm{~m} \mu$. The absorbance of this preparation at $0.05 \mathrm{mg} / \mathrm{ml}$ was 0.62 . Cut roots and boiled roots served as controls.

Identification of lignin DLS was characterized by infrared (IR) and ultraviolet (UV) absorption spectra, by determination of methxoyl groups, and by paper chromatography of the degradation products. $\mathrm{KBr}$ tablets were used for IR absorption determinations. The UV absorption spectra of $0.1 \mathrm{mg} / \mathrm{ml}$ DLS were taken in $80 \%$ dioxane solution. Methoxyl groups were quantitatively determined by Vieböck-Brecher's method ${ }^{7)}$. For paper chromatography, $50 \mathrm{mg}$ DLS were degraded at $180^{\circ} \mathrm{C}$ for $2 \mathrm{hr}$ in a mixture containing $20 \mathrm{ml}$ of $2 \mathrm{~N} \mathrm{NaOH}$ and $0.5 \mathrm{ml}$ of nitrobenzene. To remove residual nitrobenzene, the reacted solution was steam-distilled. After acidification to $\mathrm{pH} 1.5$ with $3 \mathrm{~N} \mathrm{HCl}$, the solution was continuously extracted with ether for $70 \mathrm{hr}$. The ether extract was dissolved in $1 \mathrm{ml}$ of $95 \%$ ethanol and the solution was applied to sheets of Tôyô filter paper (No. 50). Chromatograms were run in $n$-butanol solvent saturated with $3 \%$ ammonium hydroxide. To identify vanillic acid, $1 \%$ ethanol solution of quinone chloroimide and $1 \% \mathrm{Na}_{2} \mathrm{CO}_{3}$ were used as a spray after exposure of the filter paper to acetic acid vapor. For vanillin, $p$-hydroxybenzaldehyde, and syringaldehyde, a solution containing 1\% 2,4-dinitrophenylhydrazine in $5 \% \mathrm{HCl}$ was used. Each spot was extracted with $5 \mathrm{ml}$ of $95 \%$ ethanol for $24 \mathrm{hr}$, and the amounts were measured at $306 \mathrm{~m} \mu$ (for vanillin and syringaldehyde), at $286 \mathrm{~m} \mu$ (for $p$ hydroxybenzaldehyde), and at $260 \mathrm{~m} \mu$ (for vanillic acid). The relationship between extraction period and extracted amount of the degradation products obtained from the separated spots of paper chromatogram was shown by the following equation:

$$
\mathrm{Y}=\frac{\mathrm{X}}{0.0111+0.0089 \mathrm{X}} \text { (where } \mathrm{Y}: \text { Extracted amount (\%); X: Extraction period (day)). }
$$


The absorbances of vanillin, syringaldehyde, $p$-hydroxybenzaldehyde, and vanillic acid at $0.01 \mathrm{mg}$ $/ \mathrm{ml}$ were $0.74,0.69,1.40$, and 0.60 , respectively.

\section{Results and discussion}

Conidia formation on excised sections Table 1 shows number of conidia produced on excised sections. Illumination was found to be necessary for conidial formation. Figs. 1, 4, 5, in Plate I show haustoria, conidiophores and conidia on the sections.

Sites of lignification and peroxidase activity Fig. 1 shows camera-lucida drawings of transverse and longitudinal sections of the Japanese radish root. The roots consist mostly of xylem parenchyma ${ }^{10)}$. Plate II shows the reactions of infected and noninfected roots to phloroglucinol-HCl and Loele's reagents. Immediately after inoculation, lignin formation was observed only at the cell walls of periderm and vessels. Three days after inoculation, cell walls of parenchyma were found to be lignified. Infecting hyphae were observed near lignified cells. However, we could not observe with precision whether the lignification had taken place before or after the fungal attack. As shown in Figs. B, C, in Plate II, very little lignification was apparent for noninfected parenchyma, and this can be seen at the lower part of the infected cells 1 to 2 days after inoculation. The depth of infection in the sections 3 days after inoculation was about 1.5 $\mathrm{mm}$. Moreover, lignification in the walls of infected parenchyma was incomplete. If the ligni-

Table 1. Number of conidia formed on the excised section of downy mildewinfected Japanese radish roots

\begin{tabular}{ccccr}
\hline $\begin{array}{c}\text { Number of conidia } \\
\text { per unit area } \\
\left.\left(\mathrm{cm}^{2}\right) \mathrm{a}\right)\end{array}$ & 0 & 5 & \multicolumn{3}{c}{ Incubated daysb $)$} \\
I & 0 & 0 & 243 & 90 \\
II & 0 & 0 & 313 & 155 \\
III & 0 & 0 & 335 & 112 \\
Avg. & 0 & 0 & 297 & 119 \\
\hline
\end{tabular}

a) Average surface area of inoculated sections is $11.3 \mathrm{~cm}^{2}$.

b) Light: 110 lux, Temp.: $20^{\circ} \mathrm{C}$. fication is complete, the hyphae may not attack lignified walls and the infection may then stop. In fact, infected hyphae did not attack previously lignified vesels. (see Fig. 3 in Plate I). Peroxidase activity was also observed histochemically near lignified walls. All cells in these sections except the cut surface were alive as observed by plasmolysis (see Fig. 2 in Plate I). Until 3 days after inoculation, the browning reaction was not observed even at the surface of the sections. The browning reaction appeared about 5 days after inoculation. In these tissues host cells had already died. Therefore, it seems that the browning

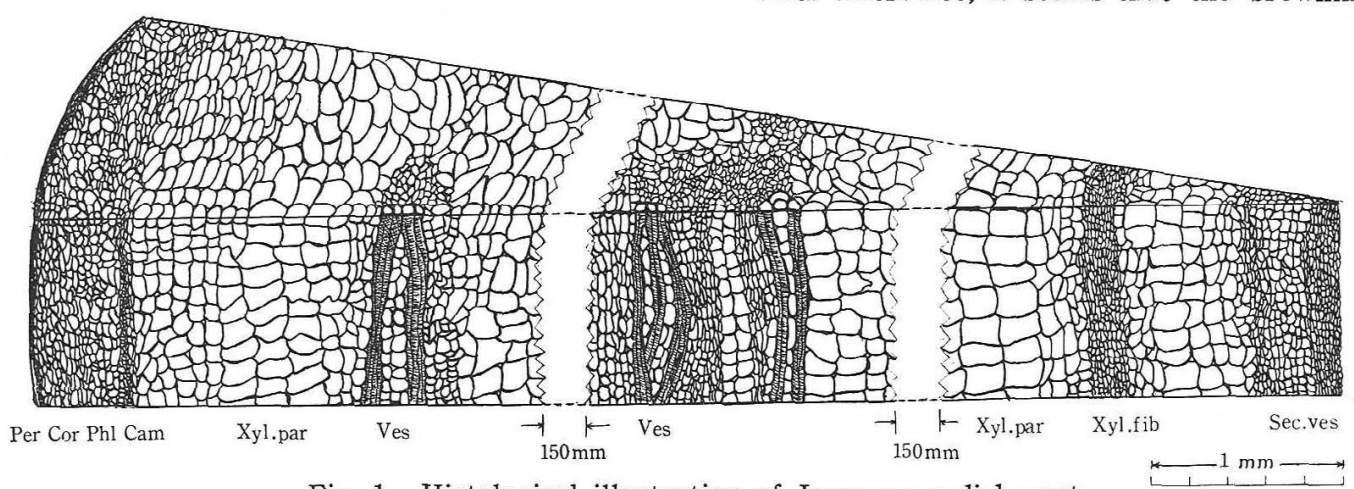

Fig. 1. Histological illustration of Japanese radish root. Per: Periderm, Cor: Cortex, Phl: Phloem, Cam: Cambium, Xyl. par: Xylem parenchyma, Ves: Vessel, Xyl. fib: Xylem fiber, Sec. ves: Secondary vessel. 
reaction does not occur as a defense reaction of the host but occurs as the result of death of the host. The cell wall of the parenchyma in control sections is not lignified even at the cut surface. Therefore it would appear that lignin formation seems to take place, not by cutting, but by fungal infection. It should be noted that living cells are necessary to form lignin. Since lignin is probably formed from enzymatic dehydrogenation of specific phenylpropane monomers, living cells may be required. DeJong ${ }^{2)}$ reported that peroxidase reaction is strongest in nonlignified tissues, but is absent in lignified xylem throughout all stages of the development of onion root. Higuchi and Ito $^{4)}$ indicated that laccase and peroxidase activities are probably responsible for dehydrogenation. Freudenberg ${ }^{3)}$ suggested the following mechanism for initiating dehydrogenation polymerization of coniferyl alcohol. The coniferyl alcohol (I) is dehydrogenated at phenolic hydroxyl group. A mesomeric radical is formed with limiting structures, such as aroxyl form (II), p-quinone methide radical (III), and orthoquinoid form (IV). The combination of<smiles>COc1ccc(C=O)cc1</smiles>

( I )

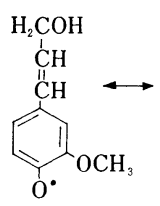

( II)

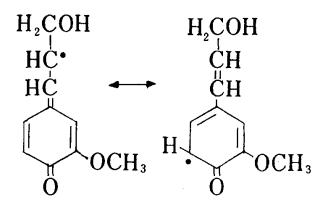

( III)

( IV) is stabilized by intramolecular prototropy, giving dehydrodiconiferyl alcohol. Two (III) radicals give a double quinone methide, which undergoes a double prototropy, giving pinoresinol. These substances seem to be components of lignin ${ }^{9}$.

Thus peroxidases, which are widely distributed in plants, and for which the activity increases following fungal infection, seem to play a role in lignin formation. The extraction and identification of peroxidases should be followed in future studies.

Identification of lignin The UV absorption spectra of DLS are shown in Fig. 2. Curves $\mathrm{A}$ and $\mathrm{B}$ show absorbances in basic and neutral dioxane solutions, respectively, and $\mathrm{C}$ shows the difference $(\Delta \varepsilon)$ between them. Curve B had a maximum at $278 \mathrm{~m} \mu$; the maximum value of $\Delta \varepsilon$

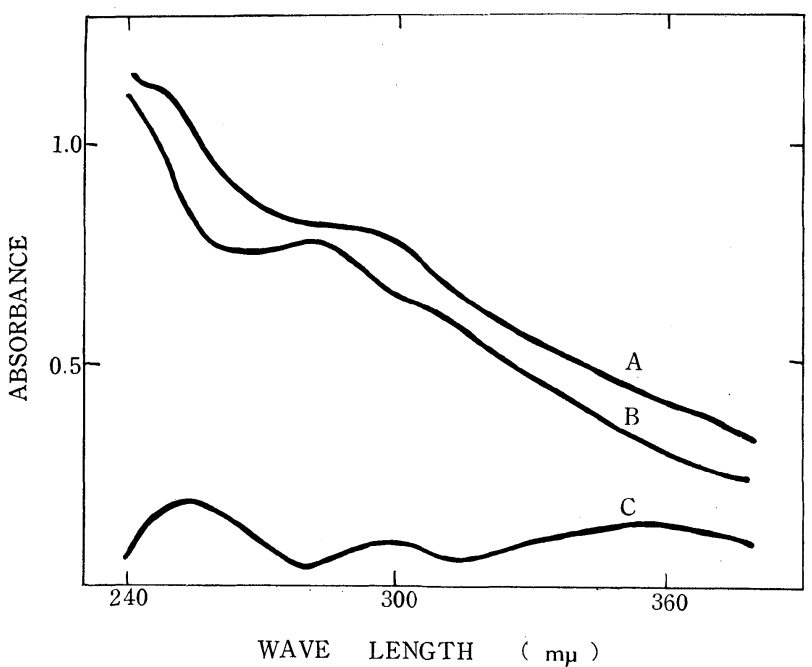

Fig. 2. U1traviolet absorption spectra and $\Delta \varepsilon$ of the isolated dioxane lignin-like substance obtained from inoculated Japanese radish root. A: Basic dioxane solution, B: Neutral dioxane solution, $\mathrm{C}: \Delta \varepsilon$. was about $300 \mathrm{~m} \mu$. Fig. 3 shows the IR absorption spectrum of DLS. Absorptions at $3,400,2,920$, and $2,850 \mathrm{~cm}^{-1}$ indicated the presence of $\mathrm{C}=\mathrm{O}, \mathrm{C}=\mathrm{C}$ aromatic, and $\mathrm{C}-\mathrm{H}$ groups, respectively. These results suggested that the isolated substance had the properties of lignin. However, since these spectra are not as well defined as those of wood lignin, some contamination or decomposition during isolation might have occurred. Moreover, since no methods have yet been devised for isolating lignin in the natural state, some chemical alteration may have occurred.

The amount of methoxyl group in DLS is shown in Table 2. This amount is higher then that from 


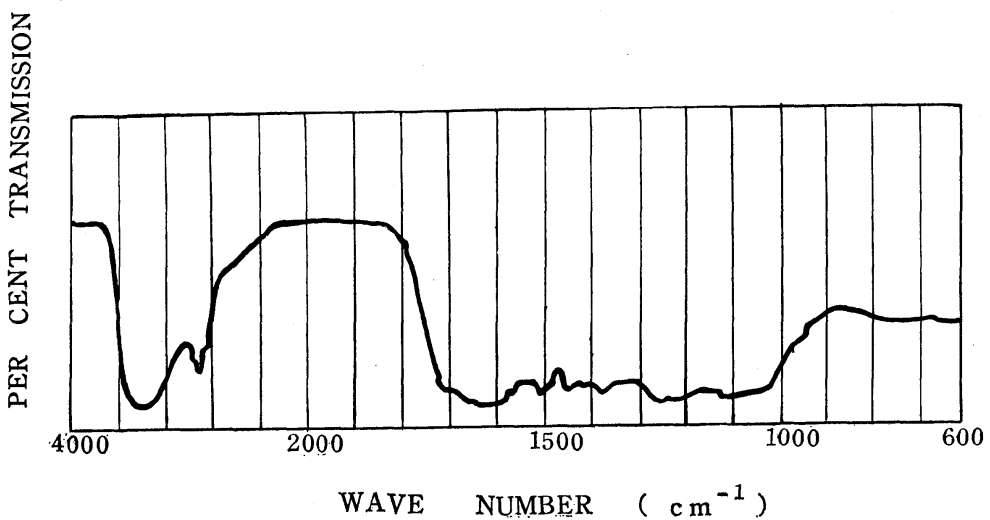

Fig. 3. Infrared absorption spectrum ( $\mathrm{KBr}$ ) of the isolated dioxane lignin-like substance obtained from inoculated Japanese radish root.

Table 2. Amount of methoxyl group in the isolated dioxane lignin-like substancea)

\begin{tabular}{|c|c|c|}
\hline $\begin{array}{l}\text { Weight of } \\
\text { sample (mg) }\end{array}$ & $\begin{array}{l}\text { Amount of } \\
\mathrm{Na}_{2} \mathrm{~S}_{2} \mathrm{O}_{3}(\mathrm{~m} l)\end{array}$ & $\left.\mathrm{OCH}_{3}(\%) \mathrm{b}\right)$ \\
\hline 4.05 & 9.6 & 12.11 \\
\hline 3.35 & 8.2 & 12.51 \\
\hline \multirow[t]{2}{*}{3.35} & 8.8 & 13.13 \\
\hline & & 12.58 \\
\hline
\end{tabular}

a) The substance was obtained from infected roots 15 days after inoculation.

b) $\frac{\mathrm{N} \times 0.0517}{\mathrm{~S}} \times 100$

where $\mathrm{N}$ : Amount of $\mathrm{N} / 100 \mathrm{Na}_{2} \mathrm{~S}_{2} \mathrm{O}_{3}(\mathrm{ml})$, $\mathrm{S}$ : Weight of sample (mg).

Table 3. $R_{F}$ values and the amounts of the degradation products by alkaline nitrobenzene oxidation of the isolated dioxane lignin-like substance

\begin{tabular}{|c|c|c|c|}
\hline Product & $R_{F}$ valuea) & $\begin{array}{l}\text { Amount } \\
(\%) \mathrm{b})\end{array}$ & Formulac) \\
\hline Vanillic acid & 0.09 & 2.76 & $\mathrm{R}-\mathrm{COOH}$ \\
\hline Syringaldehyde & 0.29 & 2.76 & $\mathrm{R}^{\prime}-\mathrm{CHO}$ \\
\hline Vanillin & 0.35 & 6.16 & $\mathrm{R}-\mathrm{CHO}$ \\
\hline $\begin{array}{l}p \text {-Hydroxybenz- } \\
\text { aldehyde }\end{array}$ & 0.44 & 1.48 & $\mathrm{R}^{\prime \prime}-\mathrm{CHO}$ \\
\hline
\end{tabular}

a) Solvent mixture: $n$-Butanol saturated with $3 \% \mathrm{NH}_{4} \mathrm{OH}$.

b) The amounts were corrected by the previously mentined equation.

c) R=Guaiacyl, R'=Sringyl, $\mathrm{R}^{\prime \prime}=$ Hydroxyphenyl. roots infected by Alternaria japonica ${ }^{1)}$. It seems that phenylpropane monomers for polymerization is different depending on the source. The DLS constituents were next examined. Table 3 shows the $R_{F}$ values and amounts of the degradation products by alkaline nitrobenzene oxidation. Vanillin was highest in amount. Fig. 4 shows the UV absorption spectra of the degradation products. The spectra of vanillic acid, vanillin, and $p$-hydroxybenzaldehyde were consistent with those of authentic compounds. However, syringaldehyde and its authentic compound differed in their spectra. Therefore, the degradation products seem not to contain syringaldehyde. DLS from roots infected by A. japonica contained $9.9 \%$ of vanillin and $0.4 \%$ syringaldehyde. Since higher amount of methoxyl group was observed in DLS from Peronospora-infected roots than that from Alternaria-infected roots, there may be differences in the DLS constituents.

Quantitative determination of lignin content It was previously shown that the amount of lignin-like substances obtained by thioglycolic acid treatment was more than 10 times that of DLS which was extracted by dioxane ${ }^{1}$. Apparently, dioxane did not extract lignin effectively. For the quantitative determination of lignin, thioglycolic acid may be a useful extracting solvent. Fig. 5 shows 

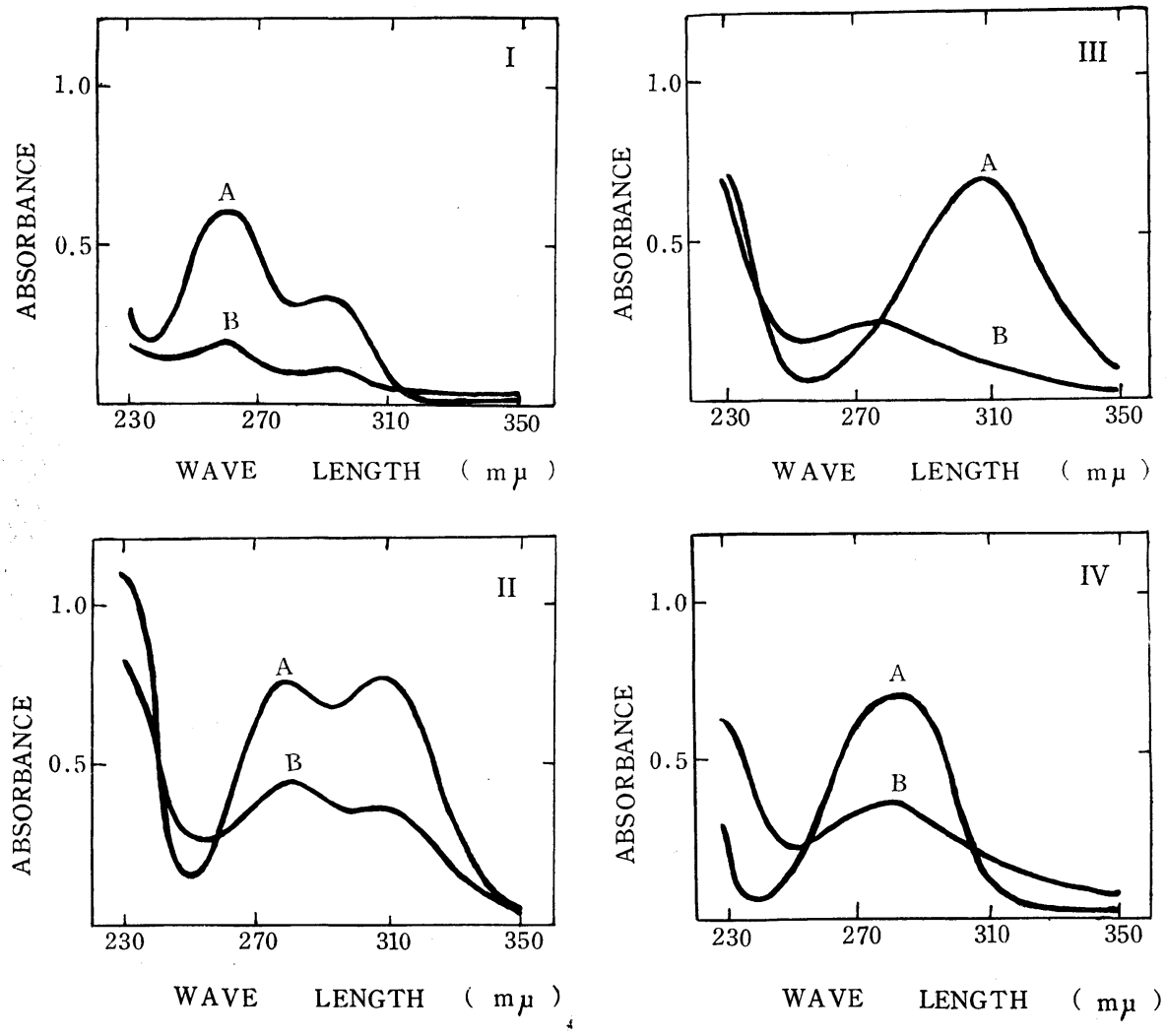

Fig. 4. Ultraviolet absorption spectra of authentic compounds and the degradation products obtained from the extraction of paper chromatograms.

A: Authentic compound, B: Degradation product, I: Vanillic acid,

II: Vanillin, III: Syringaldehyde, IV: $p$-Hydroxybenzaldehyde.

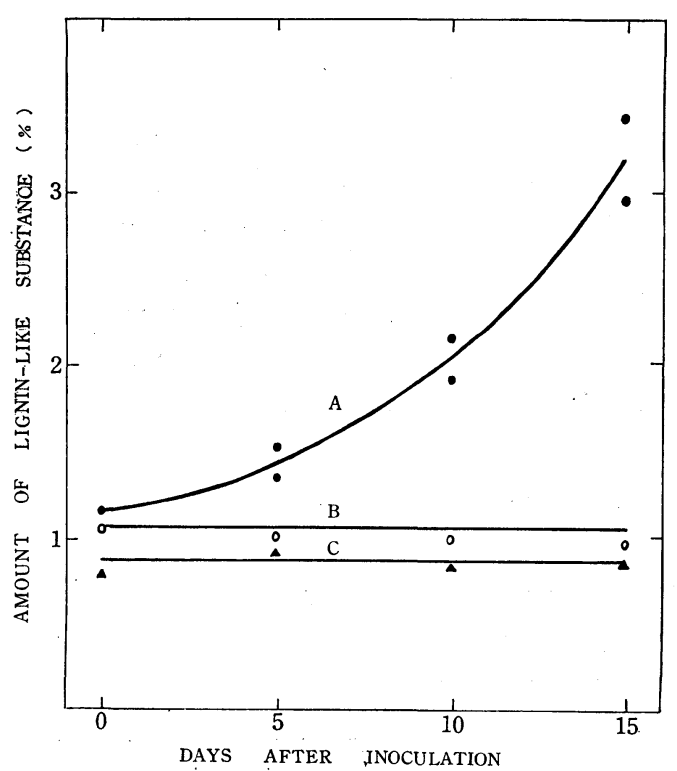

the amount of LS in roots infected or incubated without fungi. The amount increased following infection. Noninoculated and boiled roots showed no increases during incubation. These results show that lignin formation in roots takes place only in infected living tissues.

Amount of methoxyl group in the isolated dioxane lignin-like substance Table 4 shows the amounts of methoxyl group in DLS from infected or cut roots. The amount of $-\mathrm{OCH}_{3}$ decreased following infection. For comparing

Fig. 5. Changes in the amount of the isolated lignin-like substance in inoculated and noninoculated sections following infection or incubation.

A: Inoculated root, B: Noninoculated root, C: Noninoculated boiled root. 
chemical properties of lignin, it should be necessary to determine the amount of $-\mathrm{OCH}_{3}$. Coniferyl alcohol, synapyl alcohol, and $p$ coumaryl alcohol that have been proposed as precursors of lignins in plants, have 1,2 and zero molecules of $-\mathrm{OCH}_{3}$, respectively. Differences in the amount of $-\mathrm{OCH}_{3}$ in DLS may be the result of differences in the content of precursors. If we represent $A$; the total amount of LS in infected roots, B; the amount of LS in noninfected roots, $\mathrm{X}$; the calculating amount of $-\mathrm{OCH}_{3}$ in DLS of infected parenchyma, $\mathrm{C}$; the amount of $-\mathrm{OCH}_{3}$ in DLS of noninfected roots, and $\mathrm{D}$; the amount of $-\mathrm{OCH}_{3}$ in DLS of infected roots, the following equation may be taken.

$\frac{\mathrm{A}-\mathrm{B}}{\mathrm{A}} \times \frac{\mathrm{X}}{100}+\frac{\mathrm{B}}{\mathrm{A}} \times \frac{\mathrm{C}}{100}=\frac{\mathrm{D}}{100} \quad \mathrm{X}=\frac{\mathrm{AD}-\mathrm{BC}}{\mathrm{A}-\mathrm{B}}$

Table 5 shows the results of the calculation. The DLS in infected parenchyma which is freshly formed by the infection seems to be low content of $-\mathrm{OCH}_{3}$ as compared with that of DLS which is present in vascular bundles and periderms of noninfected roots. Amount of $-\mathrm{OCH}_{3}$ in Klason lignin of bamboo shoots was proportional to the intensity of the phloroglucinol- $\mathrm{HCl}$ reaction $^{6}$. In fact, we have observed histochemically the difference of the color reaction between the cell walls of vascular bundle and of infected parenchyma.

\section{Conclusion}

Since an obligate parasite can not survive in an artificial medium, living tissues must be used for the cultivation of the parasite. The use of Japanese radish root and Peronospora complex for this purpose was first proposed by Nakamura ${ }^{8)}$. Although tissue cultures of the obligate parasite-infected host are desirable, the method is very difficult and the fungal growth is slow. It is important that the forma* used be carefully identified, that samples of the same developmental stage be chosen, and that the material always be cultivated under same conditions. However, the roots used were obtained from the market, because we did not have an experimental field of our own.

Lignification in infected tissues seems to have the following meaning. Since fungi in infected tissues generally remain alive even after the cessation of enlagement of infected area, it is assumed that the infected hyphae are enclosed by a barrier formed in the host tissues. The most effective barrier to hyphal growth may be lignin. However, the lignification on cell walls of infected parenchyma was incomplete. Therefore, the walls are not lignified enough to arrest

* In this experiment, some kinds of Japanese radish ( $R$. sativus var. hortensis f. miyashige, f. minowase, — f. sempervirens) were used.
Table 4. Changes in the amount of methoxyl group in the isolated dioxane lignin-like substance in response to infection

\begin{tabular}{ccccc}
\hline \hline $\begin{array}{c}\text { Amount of } \mathrm{OCH}_{3} \\
(\%)\end{array}$ & \multicolumn{5}{c}{ Days after inoculation } \\
& 0 & 5 & 10 & $15 \mathrm{a})$ \\
\hline I & 19.77 & 16.68 & 13.94 & 13.13 \\
II & 18.87 & 17.04 & 14.26 & 12.11 \\
III & 18.17 & 17.28 & 14.94 & 12.51 \\
Avg. & 18.93 & 17.00 & 14.38 & 12.58 \\
\hline
\end{tabular}

a) See Table 2 .

able 5. Calculated amount of methoxyl roup in dioxane lignin-like substance in infected parenchymaa)

\begin{tabular}{ccccc}
\hline $\begin{array}{c}\text { Days after } \\
\text { inoculation }\end{array}$ & $\begin{array}{c}\text { Tota1 } \\
\text { amount } \\
\text { of LSb) }\end{array}$ & $\begin{array}{c}\text { Amount } \\
\text { of LS } \\
\text { formed }\end{array}$ & $\begin{array}{c}\text { Amount } \\
\text { of } \\
\text { OCH }_{3} \text { c) }\end{array}$ & $\begin{array}{c}\text { Calcul- } \\
\text { ated } \\
\text { amount } \\
\text { of } \mathrm{OCH}_{3}\end{array}$ \\
\hline 0 & 1.06 & 0 & 18.93 & 0 \\
5 & 1.43 & 0.37 & 17.00 & 11.47 \\
10 & 2.04 & 0.98 & 14.38 & 9.45 \\
15 & 3.25 & 2.19 & 12.56 & 9.50
\end{tabular}

a) All figures in $\%$.

befer to Fig. 5 .

C) Refer to Table 4. 


\section{Plate I}
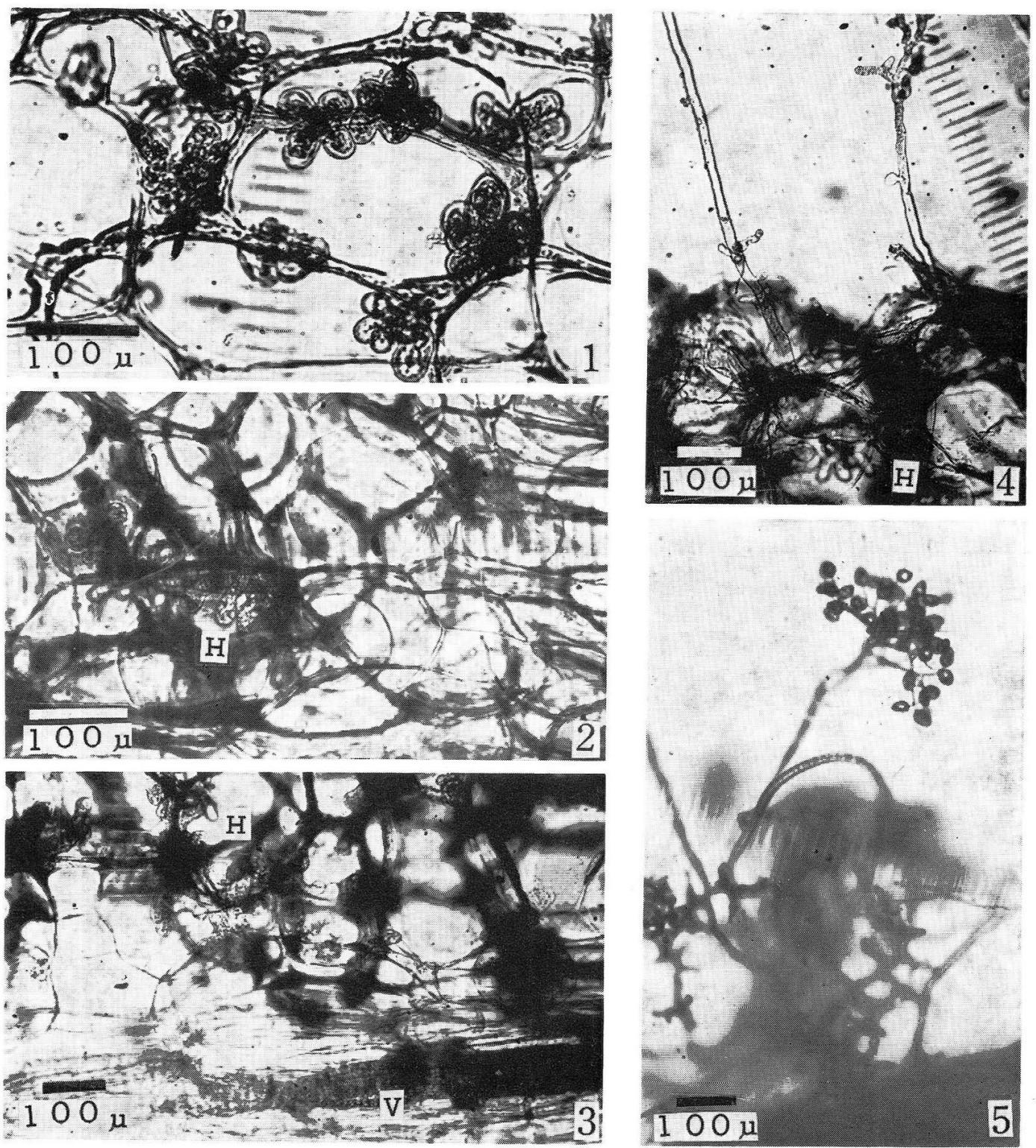

Fig. 1. Haustoria of Peronospora parasitica in parenchyma of Japanese radish root.

Fig. 2. Living cells of infected parenchyma showing plasmolysis. H: Haustoria.

Fig. 3. Infected hyphae in the section. The hyphae can not attack the lignified vessel. H: Haustoria; V: Vessel.

Fig. 4. Development of conidiophores of Peronospora parasitica on the surface of excised section 10 days after inoculation. H: Haustoria.

Fig. 5. Conidia and conidiophores of Peronospora parasitica on excised section of Japanese radish root. 


\section{Plate II}
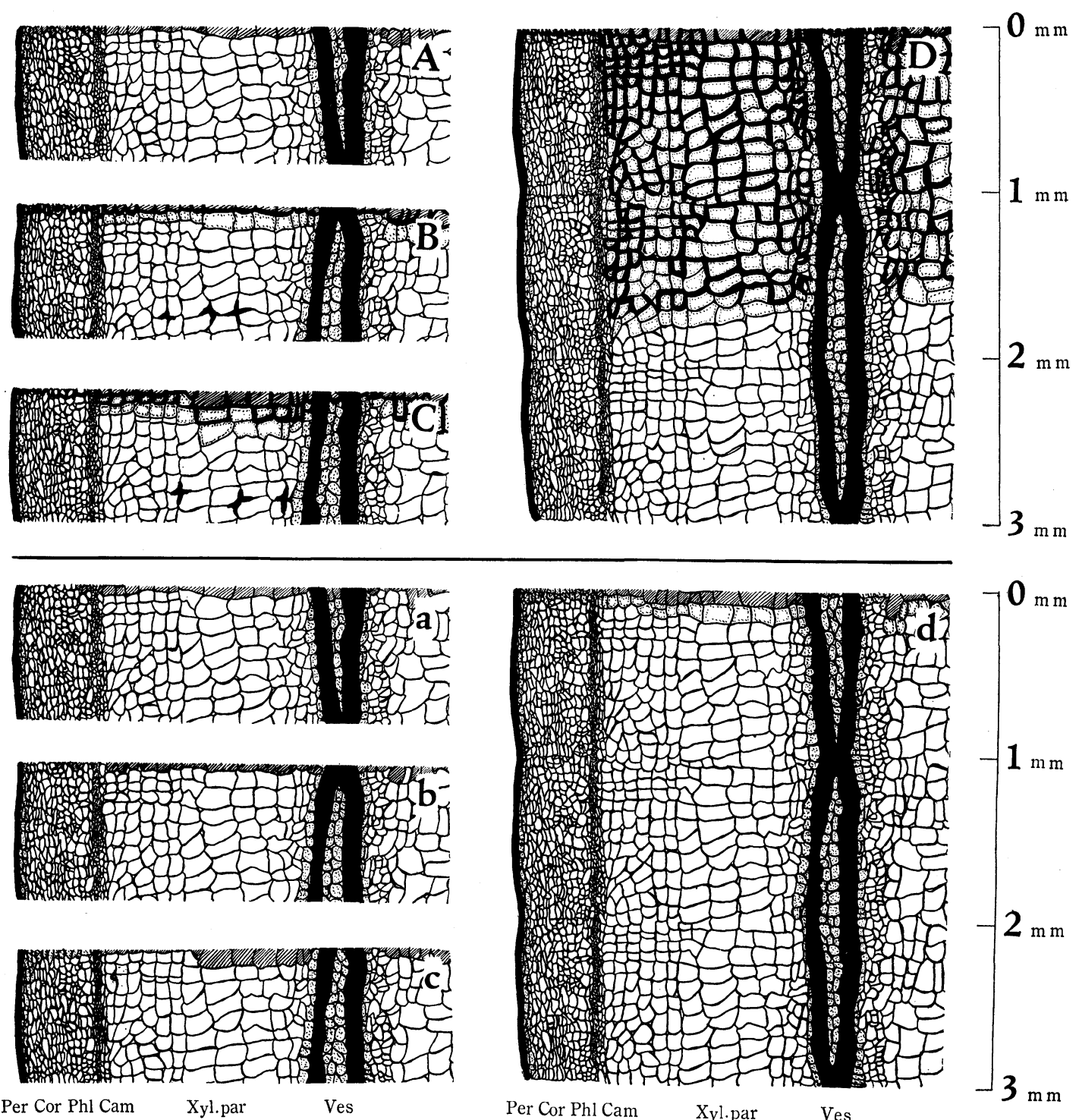

Reactions of root tissues to phloroglucinol- $\mathrm{HCl}$ (for lignin) and Loele's (for peroxidase) reagents in response to the infection of Peronospora parasitica or the incubation of section.
A: 0 day after inoculation.
B: 1 day after inoculation.
C: 2 days after inoculation.
D: 3 days after inoculation.
a: 0 day after cutting.
b: 1 day after cutting.
c: 2 days after cutting.
d: 3 days after cutting.

Per: Periderm, Cor: Cortex, Phl: Phloem, Cam: Cambium, Xyl. par: Xylem parenchyma, Ves: Vessel.

Thick parts on cell walls show the presence of phloroglucinol- $\mathrm{HCl}$ reaction. Shaded and dotted portions show dead cells and the presence of peroxidase activity. 
the fungal growth as a mechanical barrier. This fact seems to be due to the following reasons. (i) Since the excised sections used were always kept under the most favorable conditions for the fungal growth, the pathogenicity of the fungus was constantly vigorous; (ii) although high metabolic activity is required for the defense reactions in host plants, the excised sections did not have the complete activity as compared with that of the whole living plants. Moreover, the disease usually occurs not in the root but on the leaves of Japanese radish. Therefore, lignin formation in the leaves infected by the fungus is problematic. The production of phytoalexin-like substances which react to the invaded hyphae is a further problem that should be studied. The barrier hypothesis should be investigated further with special reference to the nature of disease resistance in higher plants.

We wish to express their sincere thanks to Professor T. Hirai, Nagoya University, and Professor B. O. Phinney, University of California, for reading this manuscript.

\section{Literature cited}

1. Asada, Y. and Matsumoto, I. (1967). Phytopathology 57 : 1339-1343.

2. DeJong, D. W. (1967). J. Histochem. Cytochem. 15 : 335-346.

3. Freudenberg, K. (1954). Fortschr. Chem. Org. Naturstoffe $11: 43-82$.

4. Higuchi, T. and Ito, Y. (1958). J. Biochem. $45: 575-579$.

5. Imaizumi, T. (1954). Soshiki Kagaku Oyobi Saibô Kagaku (original: Lison, L. Histochimie et Cytochimie Animales). Tokyo, p. 420.

6. Ishikawa, H. (1951). Sci. Repts. Matsuyama Agr. Coll. 6 : 63-69.

7. Miyamichi, E. (1964). Syokubutsu Seibun Bunseki Hô. Tokyo. p. 20.

8. Nakamura, H. (1960). Ann. Phytopath. Soc. Japan $23: 20$.

9. Pearl, I. A. (1967). The Chemistry of Lignin. New York. p. 94.

10. Watanabe, K. (1958). Nippon no Daikon (Nishiyama, I. ed.). Tokyo. pp. 79-97.

11. Index of Plant Diseases in the U. S. (1960). U. S. Dept. Agr. p. 105.

\section{和文摘要}

$$
\begin{gathered}
\text { ベと病菌に感染したダイ } \\
\text { リグニン根組織内に樣物質の生成 }
\end{gathered}
$$$$
\text { 浅田泰次, 松本勲 }
$$

ベと病菌に侵されたダイコン根組織はリグニン様物質を生成する。紫外拉よび赤外吸収スペクトル,メトオキ シル基量およびアルカリ分解物のペーパークロマトグラムによると，本物質は木材リグニンとは性質が異なる。 本物質はまた健全柔組織の細胞膜には存在せず,ベと病菌の感染を受けた生さた柔組織のみによって生成される。 組織化学的観察によると，木化細胞膜の近辺ではパーオキシダーゼ活性がいちじるしい。褐変は接種あるいは切 断 3 日後の切片ではその表面に㧊いてもみられない。これらの組織は切断表面を除いてすべて原形質分離を起こ す。しかし柔組織細胞膜の木化は, べと病菌の侵害に先だって起こるのか, 侵害された後の柔組織細胞膜で起こ るのかは明らかにできなかった。また侵害柔組織細胞膜での木化は部分的であり，全細胞膜が木化することはな かった。 